\title{
Chapter 6 Applied study of training projects as a learning strategy
}

Capítulo 6 Estudio aplicado de proyectos formativos como estrategia de aprendizaje

HERNÁNDEZ-CRUZ, Luz María $\dagger^{*}$, MEX-ALVAREZ, Diana Concepción, ORTIZ-CUEVAS, Nancy Georgina and CASTILLO-TÉLLEZ, Margarita

Universidad Autónoma de Campeche. Faculty of Engineering

ID $1^{\text {st }}$ Author: Luz María, Hernández-Cruz / ORC ID: 0000-0002-0469-5298, Researcher ID Thomson: H-3153-2018, CVU CONACYT ID: 662220

ID $1^{\text {st }}$ Co-author: Diana Concepción, Mex-Álvarez / ORC ID: 0000-0001-9419-7868, Researcher ID Thomson: I-4164-2018, CVU CONACYT ID: 842039

ID $2^{\text {nd }}$ Co-author: Nancy Georgina, Ortiz-Cuevas / ORC ID: 0000-0003-4191-9630, CVU CONACYT ID: 964285

ID $3^{\text {rd }}$ Co-author: Margarita, Castillo-Téllez / ORC ID: 0000-0001-9639-1736, Researcher ID Thomson: S-2283-2018, CVU CONACYT ID: 210428

DOI: $10.35429 /$ H.2021.6.86.98

L. Hernández, D. Mex, N. Ortiz and M. Castillo

*1mhernan@uacam.mx

A. Marroquín, J. Olivares, M. Ramírez and L. Cruz (Coord) Engineering and Technology. Handbooks-@ECORFAN-México, Querétaro, 2021. 


\begin{abstract}
This article analyzes the use of Training Projects as a learning strategy, a two-step methodology is carried out: the first corresponds to an applied research, in which the phases of the Training Project are implemented during the course of a learning unit (Software Project Management). The second, once the case study has been put into practice, a field investigation is applied, for the self-evaluation of the applied strategy. The data collection instrument is a survey designed with the Google Forms tool and shared via institutional email. The results of the study are promising, the use of Formative Projects in learning, they are fully aligned to the learning unit and the achievement of its competence was very satisfactory, showing that $96.1 \%$ of the students agree or fully agree that they successfully completed their projects and clearly identify the disciplinary competence achieved in the process. There is no doubt that this study opens the gap to design methodologies and/or action plans where Training Projects can contribute to the achievement of the skills of knowledge, know-how and know-how in the disciplinary field of any area.
\end{abstract}

\title{
Training projects, Competencies, Learning
}

\section{Resumen}

Este artículo analiza el uso de los Proyectos Formativos como una estrategia de aprendizaje; se lleva a cabo una metodología de dos pasos: el primero corresponde a una investigación aplicada, en la que las fases del Proyecto Formativo se implementan durante el transcurso de una unidad de aprendizaje (Proyecto de Software Gestión). En el segundo paso, una vez puesto en práctica el estudio de caso, se aplica una investigación de campo, para la autoevaluación de la estrategia propuesta. El instrumento de recolección de datos es una encuesta diseñada con la herramienta Google Forms y compartida a través de correo electrónico institucional. Los resultados del estudio son prometedores, el uso de Proyectos Formativos en el aprendizaje, están totalmente alineados a la unidad de aprendizaje y el logro de su competencia fue muy satisfactorio, mostrando que el $96,1 \%$ de los estudiantes están de acuerdo o totalmente de acuerdo en haber culminado con éxito sus proyectos e identificar claramente la competencia disciplinaria lograda en el proceso. No cabe duda, de que este estudio abre la brecha para diseñar metodologías y/o planes de acción donde los Proyectos Formativos puedan contribuir al logro de las competencias de conocimiento, saber y saber hacer en el ámbito disciplinar de cualquier área.

\section{Proyectos formativos, Competencias, Aprendizaje}

\section{Introduction}

A project is an operation of remarkable complexity, singular, with defined start and finish dates. It is a non-repetitive job that must be planned and executed according to predetermined technical specifications, with a preset budget and temporal organization, with the participation of various departments of a company later dismantled at the end of the project, and maybe the collaboration of third parties.

At some point of our academic education, we must work on certain projects, which contribute important lessons when we reach the labour market. Nevertheless, we must consider that for a project's management and execution to have a guarantee of success, it is important to know what a project is, as well as its peculiarities in both its approach and management.

Formative projects' goal is the realisation of certain activities that help to the resolution of a problem, during the course of the project, the competences determined in an educational program will be developed, in this type of project the final product is important because, based on it, the capability and the learning advances developed will be determined, as well as the realization of the acquired competences.

\section{Project}

Nowadays, "project" is one of the most daily used terms, everybody, either consciously or unconsciously, is involved in one. Neverthless, defining the concept of "project" is not easy at all, so it's best to understand its meaning. The word "project" comes from the latin "projectus" (projected), plant and disposition formed for the realisation of an agreement, or execution of something important. 
"A project is a unique mission with clearly defined objectives and results, perfectly determined start and finish dates, and most of the times, a budget" (Biafore, 2018).

The Formative Projects

"A project is an operation of remarkable complexity, singular, with defined start and finish dates. It is a non-repetitive job that must be planned and executed according to predetermined technical specifications, with a preset budget and temporal organization, with the participation of various departments of a company later dismantled at the end of the project, and maybe the collaboration of third parties" (Aceves, 2018).

The term project refers to that activity conducted to give an answer to an idea, problem or nonidentified opportunity, with a unique and concrete product or service.

According to the PMI (Project Management Institute) (PMI, 2020):

A project is a temporary entrepreneurship conducted to create a product or service. It is a process, with a defined duration and a concrete finish, composed of different tasks and activities, that can be elaborated gradually. Every project must be directed or managed by a project director. The projects direction would be the application of knowledge, skills, tools and techniques to the activities that make a project, with the goal of satisfying the requirements of the project. According to this Institute, the direction of projects is accomplished through the execution of processes, using knowledge, skills, tools and direction techniques.

A project is performing various articulated activities in order to solve a context problem. The problems can be needs, difficulties or improvement actions, creation and innovation of services, processes or products.

Figure 6.1 A project

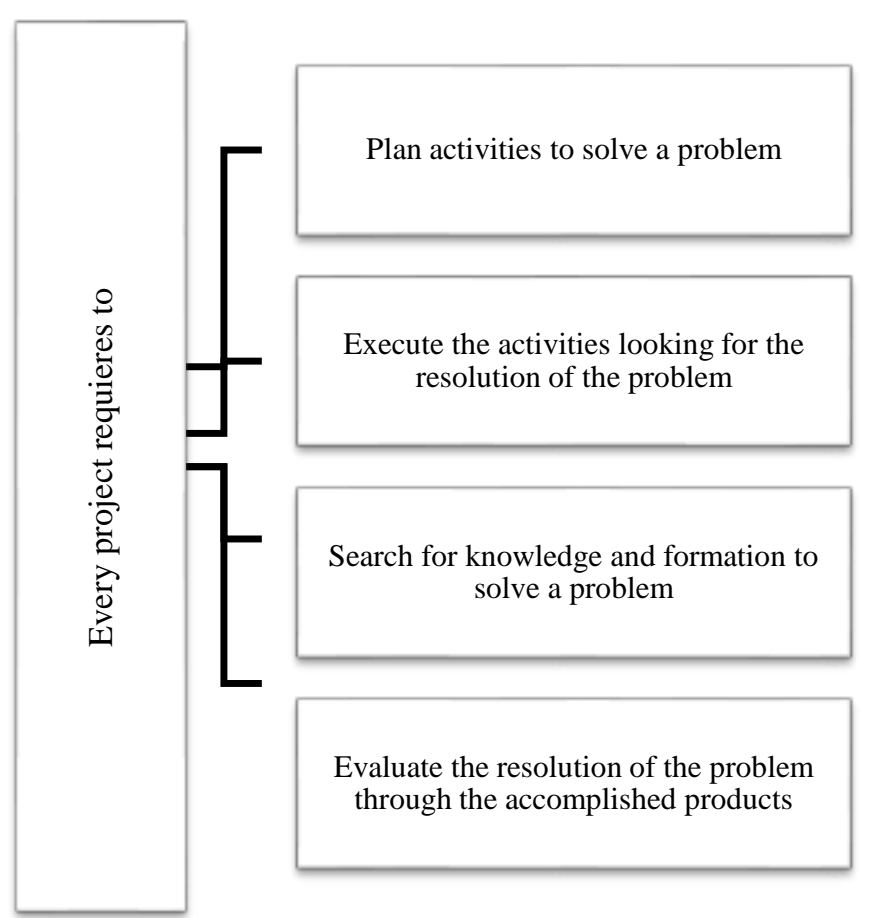

Source: (Tobón, 2014)

\section{Formative Projects}

In education, it's been proposed that students form by making projects. This way, there would be a bigger impact in the formation of entrepreneurial people. The methodology of formative projects consists in the students performing articulated activities to solve contextual problems and that way they develop the competences of the profile of graduation of a particular educational program, being very important the need to demonstrate them with evidence (products). 
Its essential characteristics according to Tobón (2013) are:

- $\quad$ Working in the context.

- Co-create knowledge.

- $\quad$ Know how to be, live, know, do.

- Solve context problems.

- $\quad$ Consider the ethical part.

Figure 6.2 A formative project

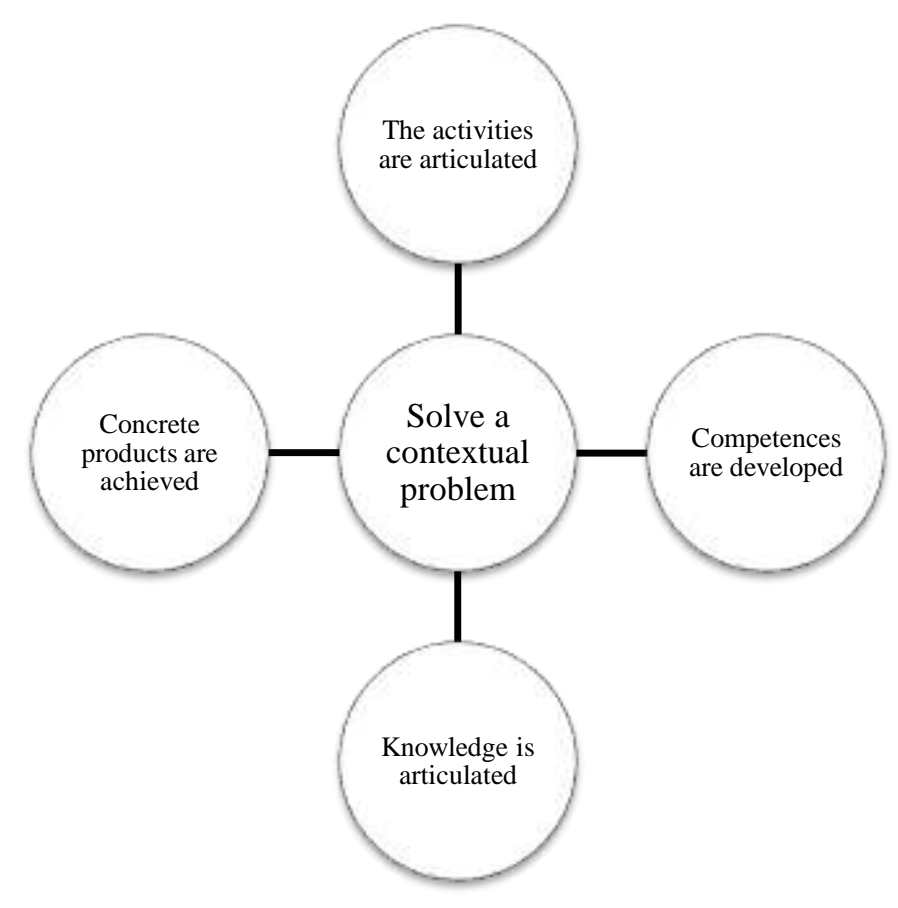

Source: (Tobón, 2014)

A formative project is structured through phases in which both professor and student participate. These phases are the scenarios where requiered learning activities are stablished for students to accomplish the defined competences. The phases of a formative project are: addressing, planning, execution and socialization (Tobón, 2010).

- $\quad$ Addressing is the phase in which it's defined between proffesors and students, the purpouse of the project, the expected competences and the evaluation process.

- In planning the students present to the instructor the project's activities to do, according to the defined purpouse in the addressing phase.

- In the execution phase the students execute the designed project with the instructor's mediation, looking for the programmed competences' achievement.

- Finally, in the socialization phase, the students present the formative project's results to the academic community. (Eva)

Formative projects have multiple benefits. The most important benefit is they make the development of competences possible in all its essence, articulating theory and practice in a meaningful context for the student, through activities that address diferent wisdoms (wisdom of being, wisdom of doing and wisdom of knowing). Also, it says that:

- $\quad$ It is learned how to apply the wisdoms in meaningful contexts

- The creativity and innovation is developed

- $\quad$ Benefits to the person, community and environmental setting are offered

- It is learned how to work in a colaborative manner 


\section{Methodology to develop}

The methodology recognizes two main steps:

- Study and implementation of the strategy "Formative projects" in the learning unit "Software Development Project Management" from the Educational Program "Computer Systems Engineering" of the Engineering Faculty in the Autonomous University of Campeche (applied research).

- Self-evaluation from the students in regards of the results obtained in the development of the generic and professional competences in the learning unit "Management of Software Projects" (field research).

Figure 6.3 Study Methodology

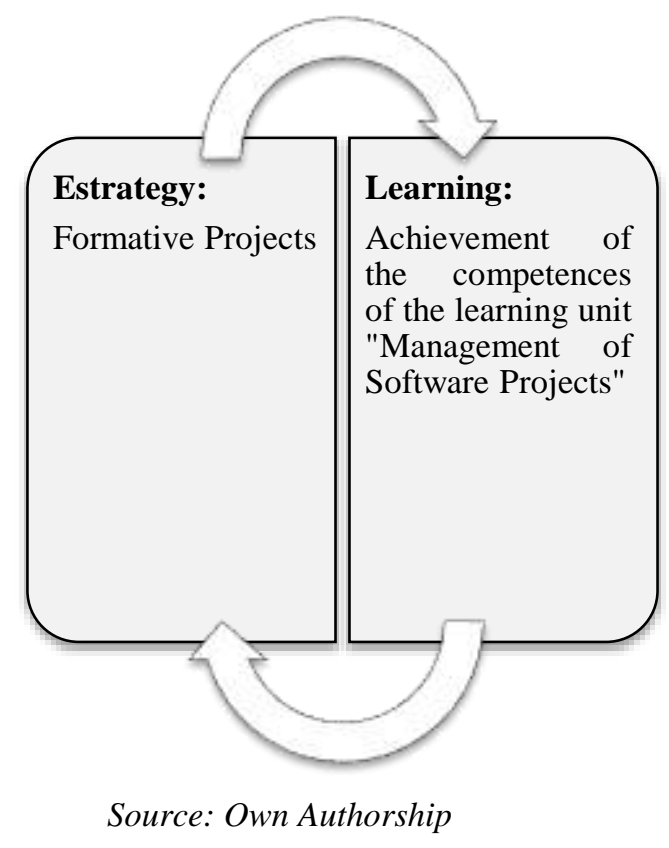

\section{Study and implementation of the strategy "Formative Projects"}

The context to conduct the investigation is the learning unit "Unidad de Aprendizaje" (UA) named "Management of Software Projects" taught in the eighth semester of the educational program Computer Systems Engineering in the Engineering Faculty of the Autonomous University of Campeche (Universidad Autónoma de Campeche), Campeche, Mexico. The UA of the nucleus: integrative, type: mandatory, area: applied engineering, credits: 4 and a total of 4 weekly hours ( 2 theorical and 2 practical) (Universidad Autónoma de Campeche).

The competence in the UA:

"To manage software projects for the development of custom computational systems, based on the standard PMBOK Guide"

A Guide to the Project Management Body of Knowledge (PMBOK® Guide) is PMI's flagship publication and is a fundamental resource for effective project management in any industry. Over the years, business has changed considerably, but projects remain critical drivers of business success. The book includes The Standard for Project Management. The standard is the foundation upon which the vast body of knowledge builds, and the guide serves to capture and summarize that knowledge.

Over the past few years, emerging technology, new approaches and rapid market changes have changed the world of work, driving the profession to evolve. A Guide to the Project Management Body of Knowledge (PMBOK® Guide) - Seventh Edition has been updated to meet these challenges, better align to how people work today and help you be more proactive, innovative and nimble.

This edition of the PMBOK® Guide: 
- $\quad$ Reflects the full range of development approaches (predictive, traditional, adaptive, agile, hybrid, etc.)

- $\quad$ Provides an entire section devoted to tailoring the development approach and processes

- Expands the list of tools and techniques in a new section, "Models, Methods, and Artifacts"

- $\quad$ Focuses on project outcomes in addition to deliverables

- $\quad$ Integrates with PMIstandards ${ }^{+\mathrm{TM}}$ for access to content that helps the user apply the PMBOK® Guide on the job

Including both The Standard for Project Management and the PMBOK® Guide, this modern edition presents 12 principles of project management and eight project performance domains critical for the effective delivery of project outcomes. The study poses the application of the Formative Projects as a learning strategy in the aforementioned UA, that allows to guarantee the accomplishment of its competence at the end of the course. Initially, the evidence for each one of the Formative Projects' development phases are defined.

Table 6.1 Evaluation Process

\begin{tabular}{|c|c|c|}
\hline $\begin{array}{l}\text { Phase of } \\
\text { Formative } \\
\text { Proyect }\end{array}$ & Description & Evidence \\
\hline Addressing & $\begin{array}{l}\text { The instructor exhibits to the students the } \\
\text { competences to accomplish, the formative project's } \\
\text { own characteristics and the methodology to follow } \\
\text { for the development of the project. }\end{array}$ & $\begin{array}{l}\text { Evidence 1: register/capture of the formative } \\
\text { project's approach }\end{array}$ \\
\hline Planning & $\begin{array}{l}\text { The students make the project's certificate of } \\
\text { incorporation, definition of the extent and the project } \\
\text { plan based on the PMBOK Guide. }\end{array}$ & $\begin{array}{l}\text { Evidence 2: documents of planning (project's } \\
\text { certificate of incorporation, definition of the extent } \\
\text { and plan for the direction of the project) }\end{array}$ \\
\hline Execution & $\begin{array}{l}\text { The students develop the project according to the } \\
\text { designed plan, following the thematic content of the } \\
\text { UA and the PMBOK Guide. In this phase, an } \\
\text { information system is created, fulfilling the } \\
\text { specifications described in the previous phase. }\end{array}$ & $\begin{array}{l}\text { Evidence 3: Software product (Information system) } \\
\text { with flawless operable functionalities alined with } \\
\text { the characterisctics and specifications described in } \\
\text { the definition of its extent. }\end{array}$ \\
\hline Socialization & $\begin{array}{l}\text { The students display their formative project to the } \\
\text { group }\end{array}$ & $\begin{array}{l}\text { Evidence 4: Multimedia presenation and/or } \\
\text { auxiliary material for the project's final product } \\
\text { (information system) presentation }\end{array}$ \\
\hline
\end{tabular}

Source: Own Authorship

Due to the characteristics of the PUA (Learning Unit Program), the weighing of the evaluation is far greater in the Second Term, because of the delivery and presentation of the finished Formative Project.

Table 6.2 Phases of the Formative Project and its percentage in the weighing of the UA

\begin{tabular}{|c|c|c|}
\hline Phase & Evaluation Report & Weighing \\
\hline Addressing & First term & $30 \%$ \\
\hline Planning & Second term & \multirow{3}{*}{$70 \%$} \\
\hline Execution & Second term & \\
\hline Socialization & Second term & \\
\hline
\end{tabular}

Source: Own Authorship

According to Formative Projects is very important to define the kind of evaluation to conduct and the tool used for it.

Table 6.3 Types of evaluation

\begin{tabular}{|l|l|l|}
\multicolumn{1}{|c}{ Phase } & Type of evaluation & Evaluation tool \\
\hline Addressing & None & None \\
\hline Planning & Heteroevaluation & Rubric \\
\hline Execution & Heteroevaluation & Checklist \\
\hline Socialization & Heteroevaluation/Self-evaluation & Rubric \\
\hline
\end{tabular}


Immediately, each phase of the Formative Project strategy is described for the raised case study.

\section{Phase 1: Addressing}

The experimentation with the students was conducted on the january-july 2021 school cycle. In the first session the instructor conducts the addressing phase. Students have one week to clarify doubts, and once work-teams are assembled, they capture in an ad-hoc Quiz the formative project to implement.

The addressing phase does not have a weighing in the student's evaluation process, so, there is no evaluation tool assigned. Evidence is not assessable, it's required. It is worth mentioning that the technological tool used in this study is Google Workspace (formerly G Suite). This way, the virtual learning platform of the UA is Classroom.

Google Classroom enables teachers to create an online classroom area in which they can manage all the documents that their students need. Documents are stored on Google Drive and can be edited in Drive's apps, such as Google Docs, Sheets, and so on. But what separates Google Classroom from the regular Google Drive experience is the teacher/student interface, which Google designed for the way teachers and students think and work. Google Classroom sits between you and Google Drive and provides a teacher/student-friendly way of managing classroom documents.

Here's what you can do with Google Classroom:

- Make assignments: The main thing you, as the teacher, will do with Google Classroom is making homework assignments for your students. When you create an assignment, you can upload the necessary documents for the students to read or work on. Students receive e-mail notification of new assignment. The students "turn in" the assignments when finished, and you can then grade the assignments.

- Make announcements: If you have a quick announcement for the entire class, you can quickly type in the announcement, which is e-mailed to all your students in the class.

- $\quad$ Store classroom materials: The materials you add to an assignment aren't the only documents you can store. You can store any other necessary documents for students on Google Drive.

- Allow students to interact: Students have the ability to comment on assignments and announcements, as well as e-mail each other through the Classroom interface.

\section{Phase 2. Planning}

The planning phase is directly related to the group of processes Management of Integration of the Project from the PMBOK Guide.

1. Develop the project's certificate of incorporation: Is the process of developing a document that formally authorizes the existence of the project and gives the director of the project the authority to apply the organization's resources to the project's activities. The key benefits of this process are that it provides a direct link between the project and the organization's strategic objectives, creates a formal register of the project and shows the organization's commitment to the project.

2. Develop the plan for the addressing of the project: Is the process of defining, preparing and coordinating all of the plan's components and consolidate them in an integrative plan for the addressing of the project.

The Project's Certificate of Incorporation is a document issued by the project's initiator or sponsor, who formally authorizes the existence of a project and gives the director of the project the authority to apply the organization's resources to the project's activities. It documents the high-level information about the project and product, service or result that the project pretends to satisfy, such as:

- $\quad$ The project's purpose

- $\quad$ The measurable objectives of the project and the associated success criteria

- The high-level requirements

- $\quad$ The high-level description of the project, the limits and the key deliverables

- $\quad$ The project's general risk 
- $\quad$ The accomplishment schedule's summary

- $\quad$ The pre-approved finantial resources

- $\quad$ The key investors list

- $\quad$ The project approval requirements (what does the project consist of who decides if the project is successful and who signs the project's approval)

- The project's release criteria (what conditions must be accomplished in order to close or cancel the project of phase)

- $\quad$ The assigned project director, its responsibility and authority level

- The name and level of authority of the sponsor or whoever authorizes the project's certificate of incorporation.

At a high level, the project's certificate of incorporation secures a common understanding by the stakeholders of the key deliverables, the accomplishments, the roles and the responsibilities of everybody involved in the project (PMBOK, 2017). The project's certificate of incorporation was evaluated with a rubric. On its behalf, according to the PMBOK Guide, the plan for the direction of the project defines the way the project is executed, monitored, controlled and closed. The plan's content for the direction of the project varies in function of the area of application and the project's complexity. The plan for the project's direction can be presented either summarized or detailed. Each plan component is described to the level required for the specific project. The plan for the addressing of the project should be robust enough to respond to the project's always changing environment.

This agility can give place to more precise information as the project advances. The base lines of the plan should be defined for the project's addressing, meaning, it is necessary to define at least the project's reference in terms of extent, time and cost, that way the execution of the project can be measured and compared with those references and the performance can be managed. Before defining the base lines, the plan for the addressing of the project can be updated as many times as necessary. Any formal process of any kind is not required in that moment. Nevertheless, once the base lines have been defined, the plan for the addressing of the project can only be modified through the process "Realizar el Control Integrado de Cambios". Therefore, every time a change is requested, change forms will be generated and decided. This results in a plan for the addressing of the project that is progressively elaborated through controlled and approved updates that extent to the project's closure.

\section{Phase 3. Execution}

In this phase the next processes are considered (PMBOK, 2017):

1. Monitor and control the project's work: This is the process of following, revise and inform the general advance in order to accomplish the pre-stablished performance objectives in the addressing of the project.

2. Make the Integrated Change Control: It is the process of revising all the change requests, approve and manage the changes for deliverables, actives of the organization's processes, project documents and the plan for the addressing of the project, as well as communicating the choices.

\section{Phase 4. Socialization}

In addition to considering the end of the Formative Project, this phase wraps the final evaluation, meaning, the competences accomplishment for the learning unit. The only process in this phase, according to the PMBOK Guide is:

1. Close the project or phase: Is the process of finishing all the activities for the project, phase or contract.

\section{Results}

The results of the investigation were oriented towards:

- Analyzing the results of the self-evaluation of the students according to the accomplishment of the learning unit's competences. 
By the nature of its objectives, the research was both field and applied, due to the use of theoretical fundamentals in order to know the nature of formative projects, the students being the source of data used for the development of disciplinary academic competences. The design of the research is exploratory descriptive, using qualitative methods for measuring frequencies, elements and categories. The universe is the eighth semester students studying the learning unit "Software Projects Management" (Facultad de Ingeniería, UAC) with a total of 38 students.

The investigation was conducted in an environment controlled by the researchers, in which a standardized survey was made using the Likert Scale from 1 to 5 (Strongly agree, Agree, neither agree or disagree, Disagree and Strongly disagree) for their answers. The instrument items' validity was made with the technique "Juicio de expertos" (Expert judgement), considering 4 university instructors, experts in the knowledge area of software engineering, particularly in Project Management and Systems Development. The instructor evaluates under two criteria: form and content. Table 6.4 shows the criteria defined with the Delphi Technique by the group of experts to evaluate the form and content criteria.

Table 6.4 Validity of the tool's content

\begin{tabular}{|l|l|}
\hline \multicolumn{1}{|c|}{ Form } \\
\hline Clarity & Coherence \\
\hline Relevance & Purpose \\
\hline Scale & Relevance \\
\hline Orthography & Identify the variables \\
\hline Presentation & Leads to the design of the methodology \\
\hline Extent & Relevance of the information \\
\hline Size and fond & Correlation \\
\hline Order & Redundancy \\
\hline
\end{tabular}

Source: Own Authorship

The student participation in the experiment was requested in a voluntary manner and through informed consent. It was emphasized that the registered information and the data analysis would only be used for means of investigative nature, respecting the confidential nature of personal data, in lined with the Federal Law of Personal Data Protection in Possession of Private Individuals, or Law of Data Protection. The research was conducted with 26 students that answered the survey in the respective reception time. The sex distribution is $80.8 \%$ women and $19.2 \%$ men. A $92.3 \%$ of the students are between 20 and 25 years old. The $57.7 \%$ of the students Agree and $30.8 \%$ Strongly Agree that the addressing phase let known the competences to accomplish through the Formative Project. As well as the criteria, types, moments and tools of evaluation. Letting it be clear that first phase of the Formative Projects strategy has had an acceptable result in the self-evaluation from the students.

Graphic 6.1 Surveyed by gender

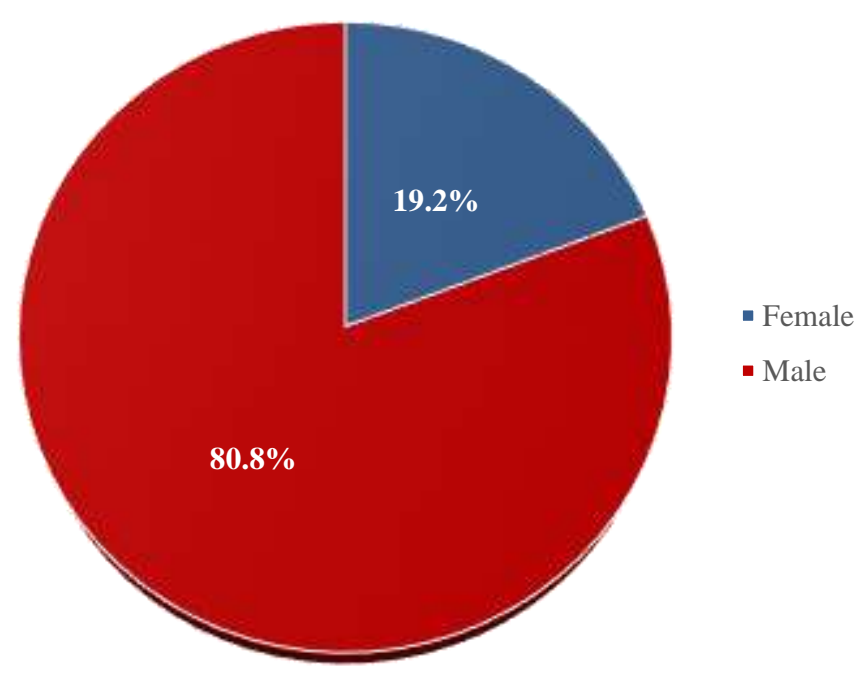

Source: Own Authorship 
Graphic 6.2 Surveyed by age

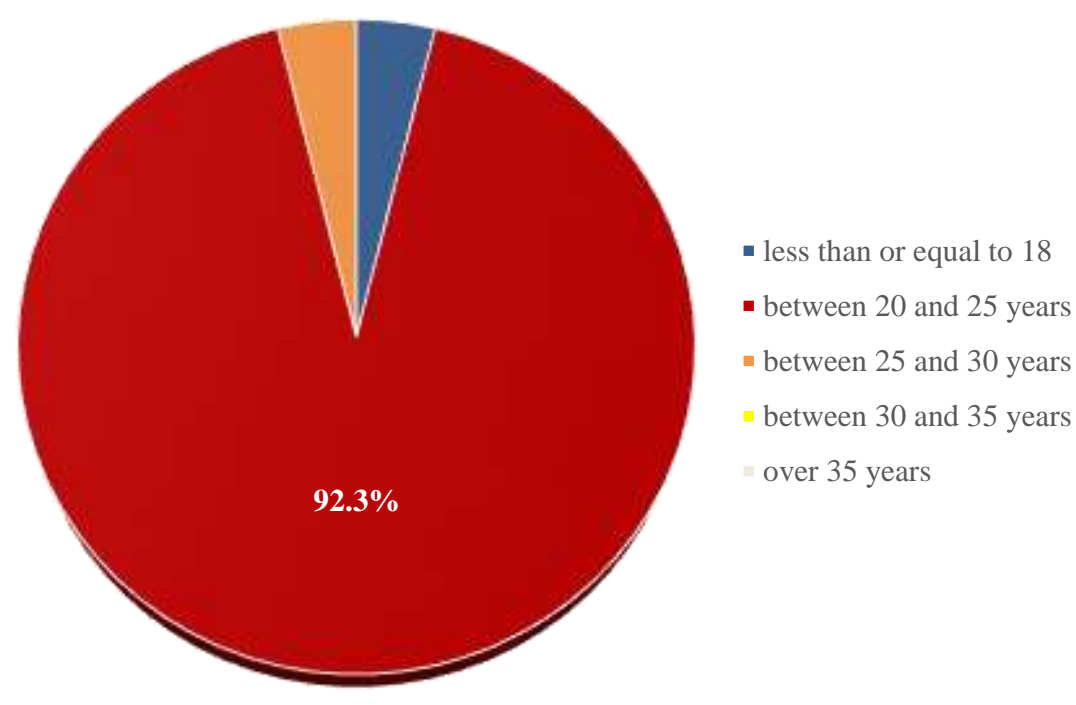

Source: Own Authorship

Despite the fact the survey was applied to students studying a learning unit correspondent to the eighth semester, with the flexibility of the educational model plus the freedom of academic load students' possess, not all of the surveyed study the last semester of the educational program. The results show that only $57.5 \%$ of the students are studying the eighth semester.

Graphic 6.3 Semester in attendance

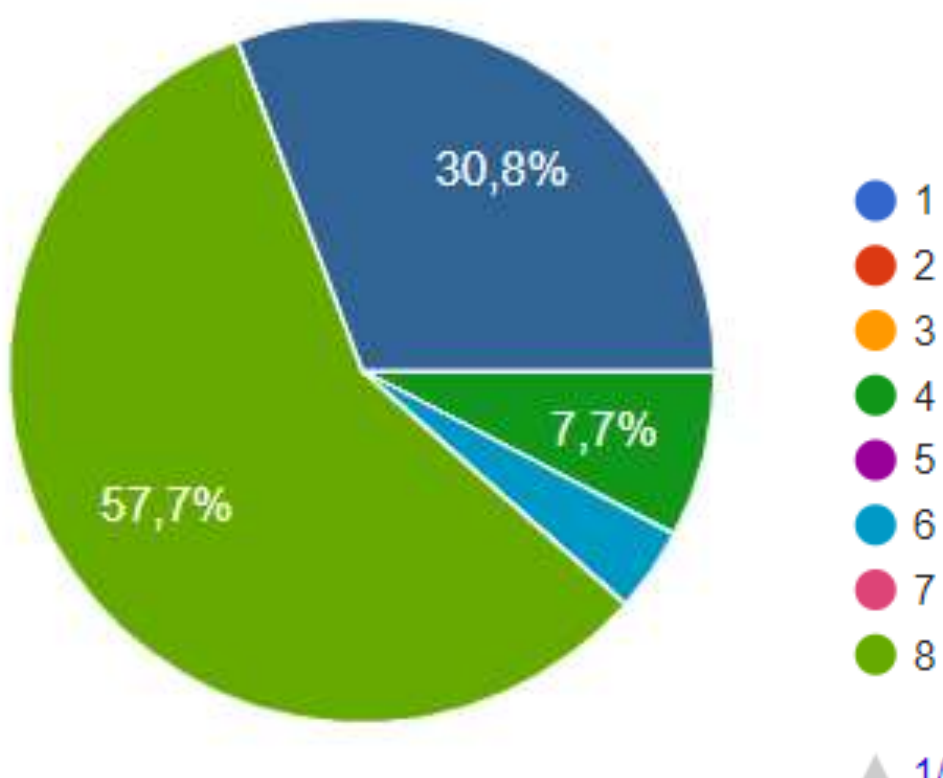

Source: Own Authorship

In the phase of addressing, it has an acceptable result, considering a $57.7 \%$ of answers were "Agree", adding a 30.8\% "Strongly agree". This phase defines an $88.5 \%$ of good understanding of the learning strategy (Formative Project) from the students. Graphic 6.4 displays the results accomplished for the addressing phase. 
Graphic 6.4 The addressing phase makes known the competences to accomplish through the Formative Project. As well as the criteria, types, moments and tools of evaluation

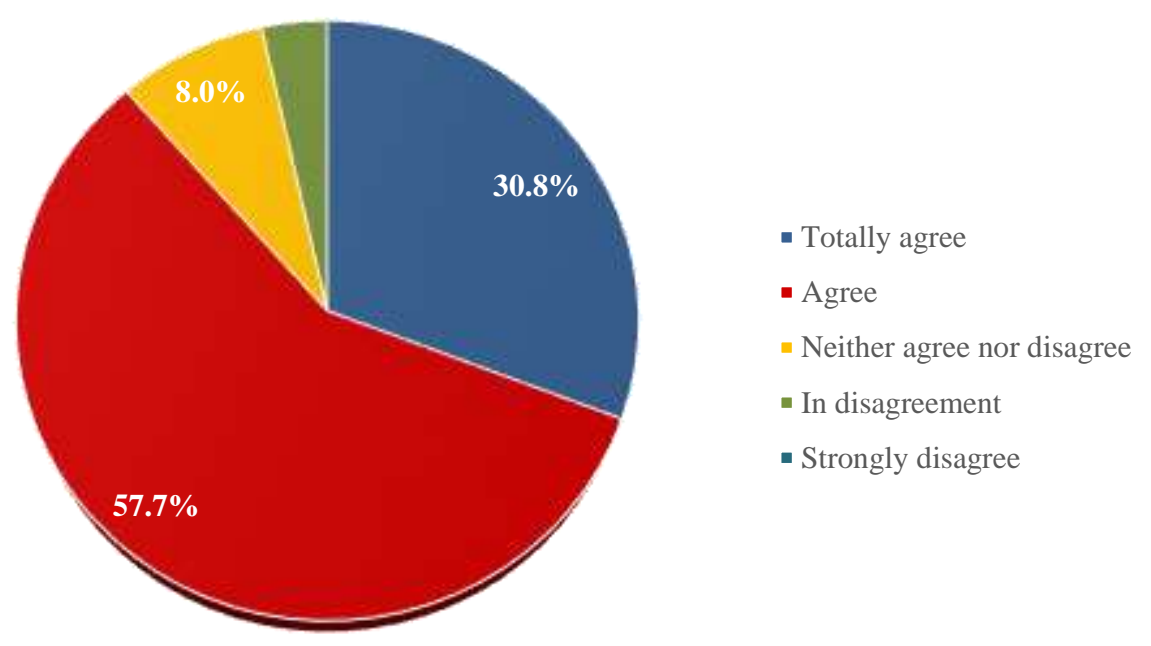

Source: Own Authorship

The planning phase obtained a $65.4 \%$ of answers on "Agree" and a $19.2 \%$ on "Strongly Agree", that way adding to a total $84.6 \%$ of positive answers to the phase. It is to be noted that the additional $15.4 \%$ answered "Neither agree nor disagree", opening to the possibility of increasing the percentage of positive appreciation. Graphic 6.5 shows the results of the planning phase.

Graphic 6.5 The planning phase allows to properly specify the requirements of the formative project.

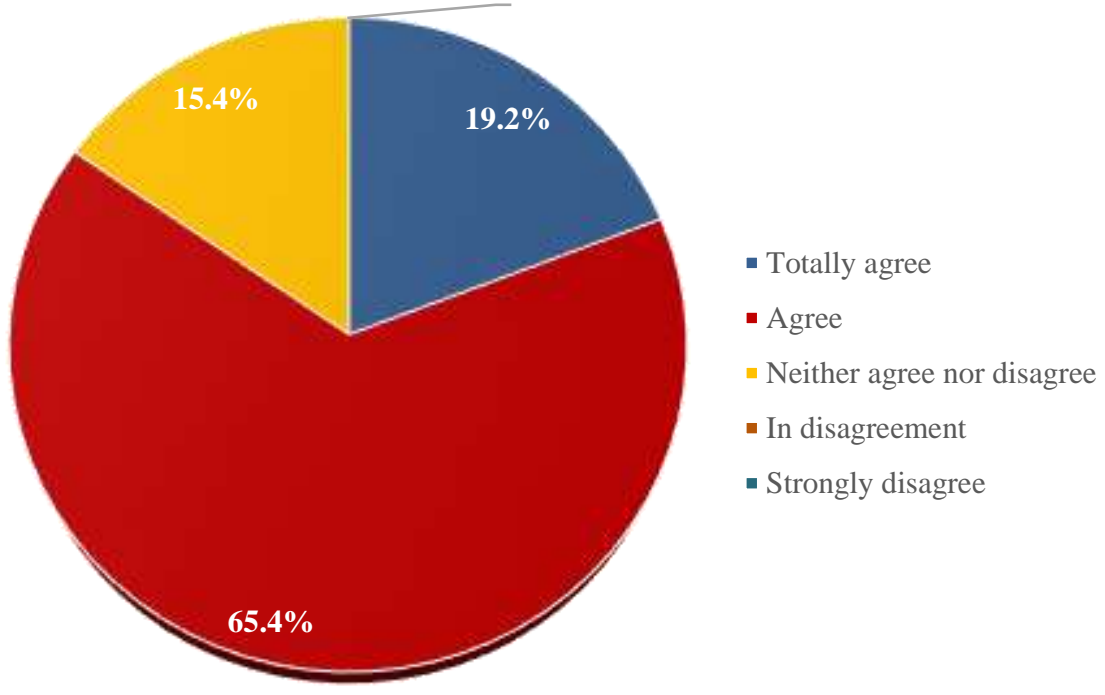

Source: Own authorship

The execution phase concerns to the development of the Formative Project including the following and control phases. The document specifically designed for that matter is the Project Plan, and the software tool of specific use is Microsoft Project 2019. The students' opinion in the self-evaluation shows that $65.4 \%$ "agree" with the obtained results managed with the so-called tool, and the other $26.9 \%$ percent "strongly agree". This adds to a total of $92.3 \%$ of surveyed in accordance with this questioning. Graphic 6.6 shows the results of the Execution phases. 
Graphic 6.6 The execution phase concerns to the development of the Formative Project including the following and control phases, whose base tool is the Project Plan, allowing to the accomplishment of the objectives

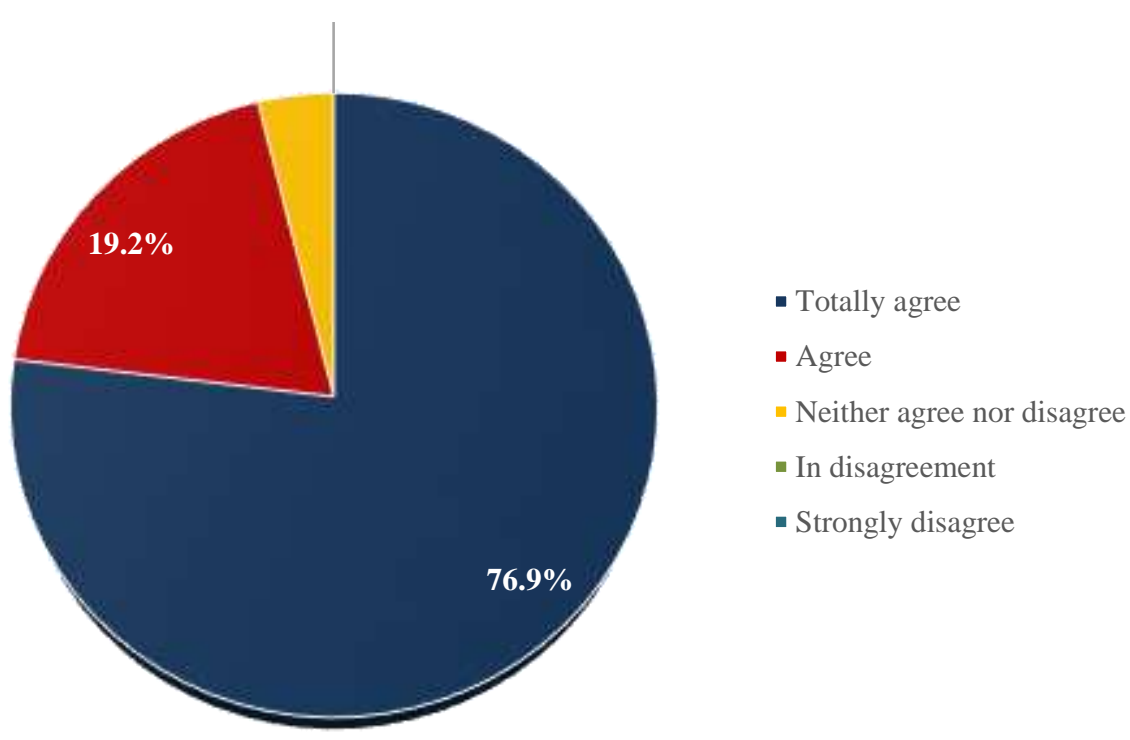

Source: Own Authorship

At last, in the closure phase the formative project finalizes with the presentation of the product (Information System), and the rating accomplished shows the goal of the competence of the learning unit. Graphic 6.7 shows the results obtained from the self-evaluation made by the students. Obtaining a $76.9 \%$ of "Strongly agree" answers and a $19.2 \%$ "agree" answers. Having a total of $96.1 \%$ of survey respondents that successfully finished their Formative Projects and are capable of distinguishing the competences they developed in the learning unit.

Graphic 6.7 The closure phase concludes with the presentation of the promised results complying with all the stablished requirements, and at the same time, showing the accomplishment of the competence of the learning unit

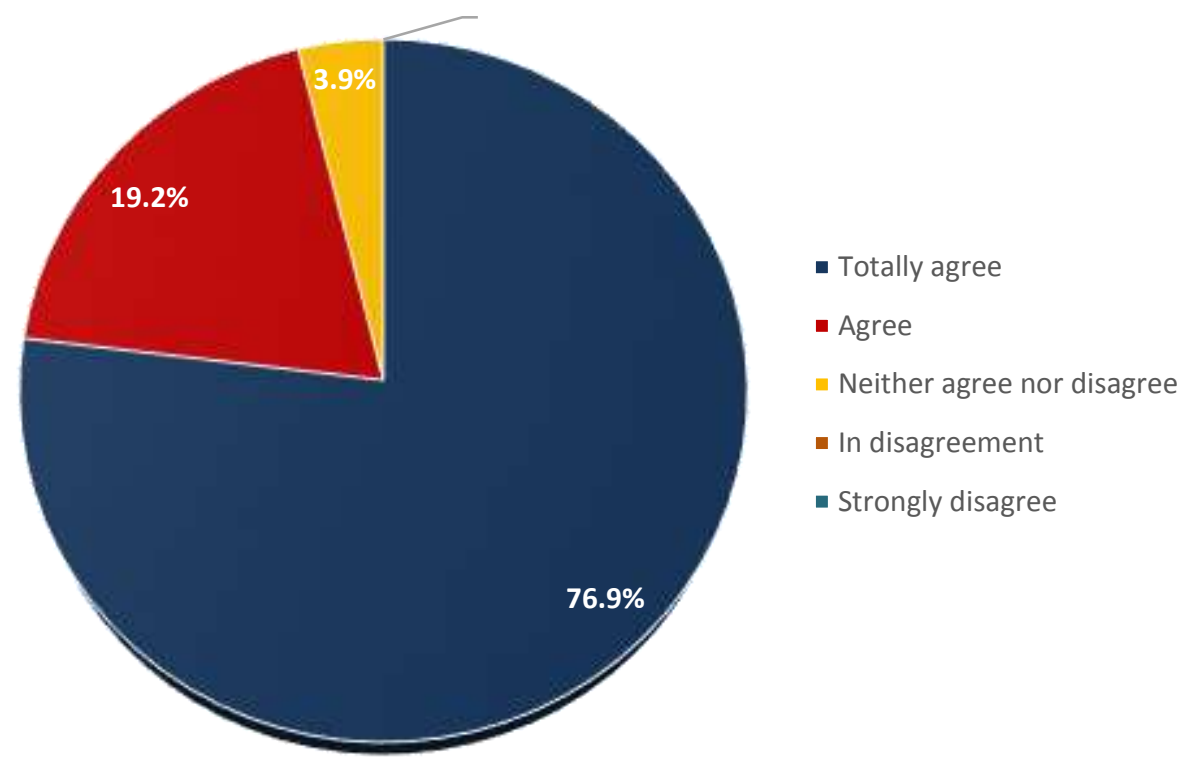

Source: Own Authorship 


\section{Acknowledgements}

Broad gratitude is extended to Prof. José Román Ruiz Carrillo, rector of the Unanimous University of Campeche for the disposition and support given for the publication of this article. Likewise, the recognition to the MAC Francisco Javier Barrera Lao, director of the Faculty of Engineering and to the Prof. Nancy Georgina Ortiz Cuevas, coordinator of the Engineering in Computer Systems Educational Program for the empathy to boost the research studies in the Computer Sciences' area.

\section{Conclusions}

The Formative Projects are a didactic method for the purpose of students to learn, construct and develop the competences of the expected profile, for the case study, to reach the competence of the learning unit. It is important not only to define the project, but to have an organized teaching-learning process composed of a group of pedagogical and communication methodologies, content management and use of tools of Technologies of Information and Communication (TICS).

About the process, it is recommended to take more emphasis to the evaluation process, defining criteria, types and tools that allow to correctly prove the knowledge and skills that students develop during the whole Formative Project process.

Certainly, the four phases of the Formative Project (addressing, planning, execution and socialization) are crucial and indispensable to successfully achieve the development of thereof. On its behalf, each learning unit from each Educational Program must initially have to make an analysis of correspondence to accurately frame the phases and be able to successfully implement the Formative Projects strategy.

Finally, the importance of the Formative Projects as a significant learning strategy, in addition to the accomplishment of the general and disciplinary competences. Another crucial factor is the collaborative work, and of course, the experience.

\section{References}

(s.f.). Obtenido de Evaluacion_de_competencias_con_apoyo_de_un_sistema.pdf

Aceves, P. (2018). Administracion de Proyectos. Enfoque por Competencias. México: Grupo Editorial.

Biafore, B. y. (2018). Gestión de Proyectos en el Mundo Real. Anaya Multimedia.

Española, R. A. (2018). Real Acedemia Española. Real Academia Española.

Ollé, C. y. (2018). Gestión de Proyectos Paso a Paso. Barcelona: UOC.

Patria. (s.f.). S.A de C.v.

PMBOK. (2017). PMBOK. PMI.

PMI. (2020).

Tobón, S. (2014). Proyectos Formativos: Teoría y Metodología. Obtenido de Person Educación: https://elibro.net/es/ereader/uacam/37979?page $=26$

Universidad Autónoma de Campeche. (enero de 2021). Facultad de Ingeniería. Obtenido de https://fi.uacam.mx/view/paginas/82 